\title{
PATHOGENICITY OF Bacillus thuringiensis ISOLATED FROM TWO SPECIES OF Acromyrmex (HYMENOPTERA, FORMICIDAE)
}

\author{
PINTO, L. M. N.., ${ }^{1,2}$ AZAMBUJA, A. O., ${ }^{1,2}$ DIEHL, E. ${ }^{1,3}$ and FIUZA, L. M. ${ }^{1,2}$ \\ ${ }^{1}$ Universidade do Vale do Rio dos Sinos, UNISINOS, Centro de Ciências da Saúde, \\ C.P. 275, CEP 93001-970, São Leopoldo, RS, Brazil \\ ${ }^{2}$ Laboratório de Microbiologia \\ ${ }^{3}$ Laboratório de Genética: Setor de Insetos Sociais \\ Correspondence to: Laura Massochin Nunes Pinto, Universidade do Vale do Rio dos Sinos, UNISINOS, Centro de \\ Ciências da Saúde, C.P. 275, CEP 93001-970, São Leopoldo, RS, Brazil, e-mail: lau@ pro.via-rs.com.br \\ Received April 16, 2002 - Accepted September 5, 2002 - Distributed May 31, 2003
}

(With 2 figures)

\begin{abstract}
The control of Acromyrmex leaf-cutting ants is necessary due to the severe damage they cause to diverse crops. A possibility was to control them using the bacterium Bacillus thuringiensis $(B t)$ that characteristically produces insecticidal crystal proteins (ICPs). The ICPs have been effective in controlling lepidopterans, dipterans, and coleopterans, but their action against hymenopterans is unknown. This paper describes an attempt to isolate $B t$ from ants of two Acromyrmex species, to evaluate its pathogenicity towards these ants, and to test isolates by PCR. Bacterial isolates of Bt obtained from $A$. crassispinus and A. lundi have been assayed against $A$. lundi in the laboratory. The bioassays were carried out in $\mathrm{BOD}$ at $25^{\circ} \mathrm{C}$, with a 12-hour photoperiod, until the seventh day after treatment. The $B t$ isolates obtained were submitted to total DNA extraction and tested by PCR with primers specific to cry genes. The results showed $B t$ presence in $40 \%$ of the assessed samples. The data from the in vivo assays showed a mortality rate higher than $50 \%$ in the target population, with the Bt HA48 isolate causing $100 \%$ of corrected mortality. The PCR results of $B t$ isolates showed a magnification of DNA fragments relative to cryl genes in $22 \%$ of the isolates, and cry9 in 67\%. Cry2, cry3, cry7, and cry 8 genes were not detected in the tested samples, and $22 \%$ had no magnified DNA fragments corresponding to the assessed cry genes. The results are promising not only regarding allele identification in new isolates, but also fort the assays aimed at determining the

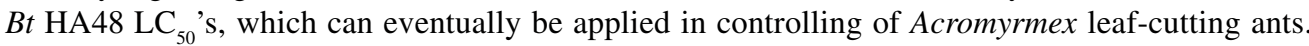

Key words: bioassay, leaf-cutting ants, Bacillus thuringiensis.

\section{RESUMO}

\section{Patogenicidade de Bacillus thuringiensis isolados de duas espécies de} Acromyrmex (Hymenoptera, Formicidae)

O controle das formigas-cortadeiras do gênero Acromyrmex é necessário em razão dos severos danos que causam a diversas culturas. Uma alternativa é a utilização da bactéria Bacillus thuringiensis (Bt), caracterizada pela produção de proteínas inseticidas eficazes para lepidópteros, dípteros e coleópteros, mas cuja ação é ainda desconhecida para himenópteros. O presente trabalho teve por objetivo isolar $B t$ a partir de formigas de duas espécies de Acromyrmex, avaliar sua patogenicidade a formigas-cortadeiras e testar por PCR. Isolados bacterianos de Bt obtidos de A. crassispinus e A. lundi foram testados contra $A$. lundi em condições laboratoriais. Os bioensaios foram conduzidos em $\mathrm{BOD}$ a $25^{\circ} \mathrm{C}$ com fotoperíodo de 12 horas, até o sétimo dia após a aplicação dos tratamentos. Os isolados de $B t$ foram submetidos à extração de DNA total e testados por PCR com primers específicos para genes cry. Os resultados revelaram a presença de $B t$ em $40 \%$ das amostras avaliadas. Os dados dos ensaios in vivo evidenciaram mortalidade 
superior a $50 \%$ da população-alvo, sendo que o isolado Bt HA48 causou $100 \%$ de mortalidade corrigida. Os resultados da PCR dos isolados de $B t$ revelaram a amplificação de fragmentos de DNA correspondentes aos genes cry 1 em $22 \%$ dos isolados e cry 9 em $67 \%$. Os genes cry2, cry3, cry 7 e cry 8 não foram detectados nas amostras testadas e $22 \%$ dos isolados não amplificaram fragmentos de DNA correspondentes aos genes cry avaliados. Os resultados são promissores tanto na identificação dos genes presentes nos novos isolados quanto nos ensaios de determinação da $\mathrm{LC}_{50}$ de $B t \mathrm{HA} 48$, que poderá ser aplicado no controle biológico de formigas-cortadeiras.

Palavras-chave: bioensaio, formigas-cortadeiras, Bacillus thuringiensis.

\section{INTRODUCTION}

The ants of Acromyrmex genus, also known as leaf-cutting ants, are responsible for damage to several crops (Diehl-Fleig, 1995). Controlling these ants has been a constant; concern, generating frequent use of chemical methods (Boaretto \& Forti, 1997). The search for alternatives with less environmental impact is increasing. Biological control which uses negative interactions between organisms is a promising alternative (Atlas \& Bartha, 1998). Among the entomopathogens, only fungi have been used to control leaf-cutting ants (Alves, 1998); bacterial potential for controlling insect pests in cultivated plants remains unknown.

Bacillus thuringiensis $(\mathrm{Bt})$ produces proteins or endotoxins with highly biopesticide effects on certain representative insect species among the orders Lepidoptera, Diptera, and Coleoptera (Höfte \& Whiteley, 1989; Schnepf et al., 1998). These proteins are coded by cry genes, which have all been detected in $B t$ isolates through the polimerase chain reaction PCR (Juárez-Pérez et al., 1997; Hansen et al., 1998). However, what is unknown is the in vivo and in vitro effect of this bacteria on Hymenoptera (Schnepf et al., 1998), specially leaf-cutting ants. Isolation and gene analysis by PCR of the $B t$ isolates from ants of Acromyrmex genus was the goal of this experiment. The present work also aims at adapting an appropriate bioassay method to leaf-cutting ants and applying it in pathogenicity assays of the new isolates.

\section{MATERIAL AND METHODS}

Samples isolation: $B t$ isolates were obtained from 80 Acromyrmex crassispinus and A. lundi workers collected in rice field areas of Instituto Riograndense do Arroz (IRGA, Cachoeirinha, RS). The insects were stored at $(-) 18^{\circ} \mathrm{C}$ in dry glass containers, in ten-individual groups. Eight samples, with ten ants each, were macerated in isotonic buffered saline solution and pasteurized. Fractions of $100 \mu \mathrm{L}$ were inoculated onto nutrient agar plates (Oxoid, UK) and incubated at $30^{\circ} \mathrm{C}$ for 24 hours. The grown bacterial colonies were morphologically analyzed with stereomicroscope and a colony counter. Following the OMS method (De Barjac \& Lecadet, 1976), each sample was inoculated in nutrient medium (Oxoid, UK), containing 10,000 Units of Penicillin-G, incubated at $30^{\circ} \mathrm{C}$, and rotated at $180 \mathrm{rpm}$ for 24 hours. The samples with bacterial growth were examined by phase-contrast microscopy and those with visible parasporal inclusions were classified as B. thuringiensis.

Insect bioassays: the bacterial bioassays against $A$. lundi were performed using two types of diet (described by Bueno et al., 1997) as a first step to assess the insects' longevity. The solid diet (SD) consisted of $5.0 \%$ glucose, $1.0 \%$ bacteriological peptone, $0.1 \%$ yeast extract, and $1.5 \%$ bacteriological grade agar. The liquid diet (LD) contained the same components as the SD, without bacteriological agar. Tests were carried out in covered glass flasks $(9 \mathrm{~cm} \times 5 \mathrm{~cm})$ containing five ants. In each flask a $2.5 \mathrm{~cm}$ diameter acrylic mini-plate was placed. For SD tests, a diet disk of around $0.5 \mathrm{~g}$ was put on each mini-plate, and for LD a cotton ball was moistened with $1.5 \mathrm{~mL}$ of LD. Six series were prepared, each one with five $A$. lundi workers: (1) control with sterilized water changed each 24 hours; (2) control with sterilized water changed each 48 hours; (3) SD changed each 24 hours; (4) SD changed each 48 hours; (5) LD changed each 24 
hours; and (6) LD changed each 48 hours. The flasks were incubated at $25 \pm 2{ }^{\circ} \mathrm{C}$ with $65 \pm 5 \%$ relative humidity and 12 hour photoperiod. This experiment was conditioned in a moist chamber on biological oxygen demand (BOD).

In the second step, corresponding to $B t$ selective assays, the same ant species used were collected in the Universidade do Vale do Rio dos Sinos Campus (UNISINOS, São Leopoldo, RS) around four hours before performing the experiments. In these bioassays, nine isolated $B t$ were grown in usual glicosed medium (De Barjac \& Lecadet, 1976) for 48 hours at $30^{\circ} \mathrm{C}$ and $180 \mathrm{rpm}$ rotation. The suspensions were centrifuged at $5000 \mathrm{rpm}$, at $4^{\circ} \mathrm{C}$ for 15 minutes; the supernatant was discarded and the bacterial suspension homogenized with LD to $1 / 3$ of the initial volume of the culture corresponding to $1-125 \times 10^{8}$ cells $/ \mathrm{ml}$. After 48 hours the $B t$ suspension was replaced by a diet without bacteria and changed regularly each 48 hours. The treatments were carried out with ten A. lundi workers. Mortality was recorded after seven days. Bioassays were conducted under the conditions described previously. The data mortality were corrected by Abbott's formula (1925).

Bt analysis by PCR: $B t$ isolates obtained from A. crassispinus and A. lundi were cultivated on nutrient agar (Oxoid, UK) at $30^{\circ} \mathrm{C}$ for about 12 hours and submitted to total DNA extraction according to the method described by Hansen \& Hendriksen (2001). The primers used were described by Ben-Dov et al. $(1997,1999)$ and Bravo et al. (1998), aiming at the detection of cryl, cry 2 , cry3, cry $7 / 8$, cry 8 , and cry 9 genes. Amplification was carried out in a DNA thermocycler (PTC-100, MJ Research, Inc.) at 35 cycles each. The reactions were carried out in volumes of 25 $\mu \mathrm{L}$ with $1 \mu \mathrm{L}$ of DNA sample mixed with reaction buffer, $0.2 \mathrm{mM}$ of each dNTP, 0.2-0.5 mM of each primer, and $0.5 \mathrm{U}$ of Taq DNA polymerase (Gibco$\mathrm{BRL})$. The samples were denatured for $1 \mathrm{~min}$ at $94^{\circ} \mathrm{C}$, annealed to primers for $40-50 \mathrm{~s}$ at $60^{\circ} \mathrm{C}$; extension of PCR products was reached for 50 $90 \mathrm{~s}$ at $72^{\circ} \mathrm{C}$. Known reference strains $(B t$ tenebrionis and Bt aizawai - positive control) were supplied by the Bacillus Genetic Stock Center (Columbus, Ohio) and the International Entomopathogenic Bacillus Center (Institut Pasteur, Paris). Negative control was prepared in the same conditions, without DNA addition. PCR products amplified were analyzed in agarose gel (1-1.5\%).

\section{RESULTS AND DISCUSSION}

Lack of data on the specificity of Cry proteins against leaf-cutting ants, determined the strategy chosen to obtain $B$. thuringiensis isolates from the target insect that had not been included in the $B t$ spectrum of action (Schnepf et al., 1998). A similar method was used by Bernhard et al. (1997) in isolating $B t$ from natural samples collected on all continents.

The data revealed 35 Bacillus sp. isolates from A. crassispinus and A. lundi workers. The phasecontrast microscopy results showed the presence of crystals in $40 \%$ of these, corresponding to identification of $14 \mathrm{~B}$. thuringiensis isolates.

The liquid diet and the system of changes at 48-hour intervals showed the best result in determining the leaf-cutting ant bioassay method. All of the ants survived up to 180 hours ( 7.5 days). These results showed that this bioassay method may be used in selective assays of $B t$ against the target species, with evaluation done for up to 168 hours (7 days) (Fig. 1).

The pathogen effect results using the new $B t$ isolates against $A$. lundi, showed that three isolates caused mortality of between $50 \%$ to $100 \%$ (Table 1); $B t$ HA48 isolate caused the highest mortality (100\%) followed by Bt HA58 (80\%).

The in vivo isolates selected as pathogenic to A. lundi were analyzed by PCR in order to verify the presence or absence of cry genes already known as active against other insect orders, as described by Schnepf et al. (1998). Fig. 2 shows the PCR analysis for the nine $B t$ isolates, obtained from the ants, with DNA amplifications corresponding to $c r y 1$ genes $(22 \%)$ and cry9 $(67 \%)$. The cry 2, cry 3, cry 7 , and cry 8 genes were not detected in the tested samples. It bears mention that to date the cryl and cry 9 genes have been described as specific for lepidopterans (Schnepf et al., 1998; Maagd et al., 2001). However cryl genes have already been refered to as active against a Coleoptera species (Naimov et al., 2001). Our data suggest that the Cry protein insecticidal spectrum may be wider that than until now known and described. 


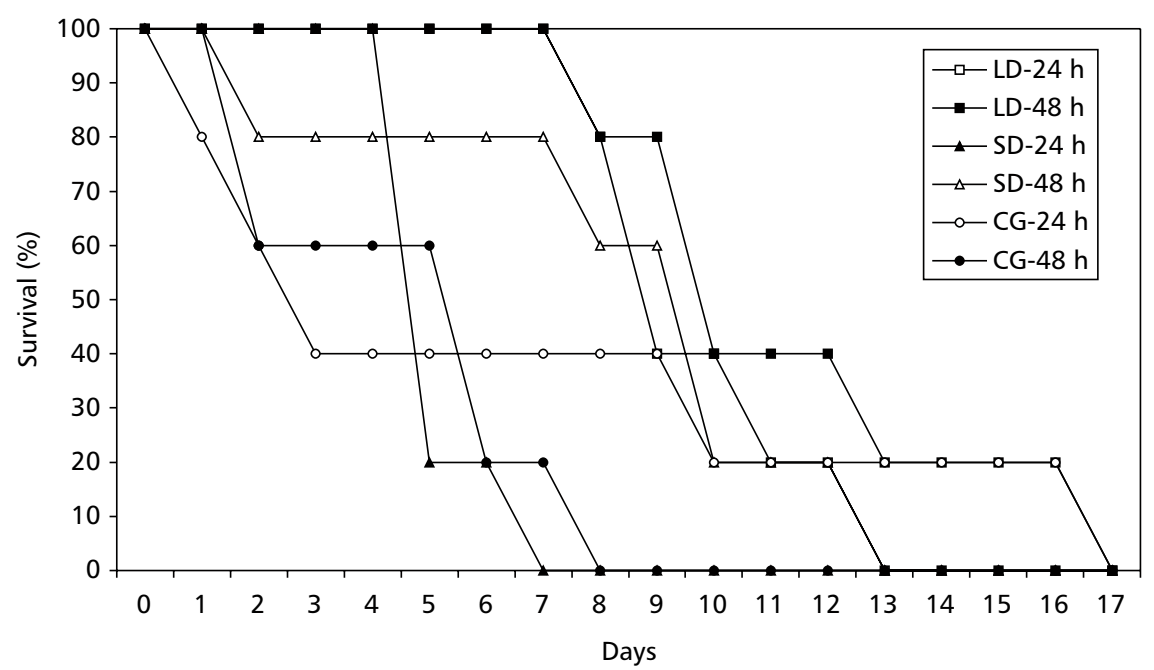

Fig. 1 - Acromyrmex lundi survival in liquid diet (LD); solid diet (SD); and control group (CG; sterilized water).

Regarding all $B t$ isolates evaluated in the present study by PCR, it should be noted that $22 \%$ showed no amplification of DNA fragments corresponding to the Bt cry genes analyzed. The isolates with no PCR products corresponding to the tested genes may belong to another known class, or can represent a new cry gene class. This research shows results encouraging further investigation on the unknown genes present in the new isolates, as well as $B t$ HA48 LC $_{50}$ evaluation.

TABLE 1

Characterization and pathogenicity of Bacillus thuringiensis isolates against Acromyrmex lundi.

\begin{tabular}{|c|c|c|}
\hline$B t$ isolates & Cry genes presence ${ }^{a}$ & Mortality $(\%)^{b}$ \\
\hline HA01 & - & 12,5 \\
\hline HA02 & cry9 & 12,5 \\
\hline HA03 & - & 50,0 \\
\hline HA48 & cry9 & 100,0 \\
\hline HA52 & cryl, cry9 & 42,8 \\
\hline HA53 & cry9 & 14,3 \\
\hline HA56 & cry 9 & 20,0 \\
\hline HA57 & cry 9 & 40,0 \\
\hline HA58 & cryl & 80,0 \\
\hline
\end{tabular}

${ }^{a}(-)$ negative by primers tested; ${ }^{b}$ corrected mortality until $7^{\text {th }}$ day after treatments. 


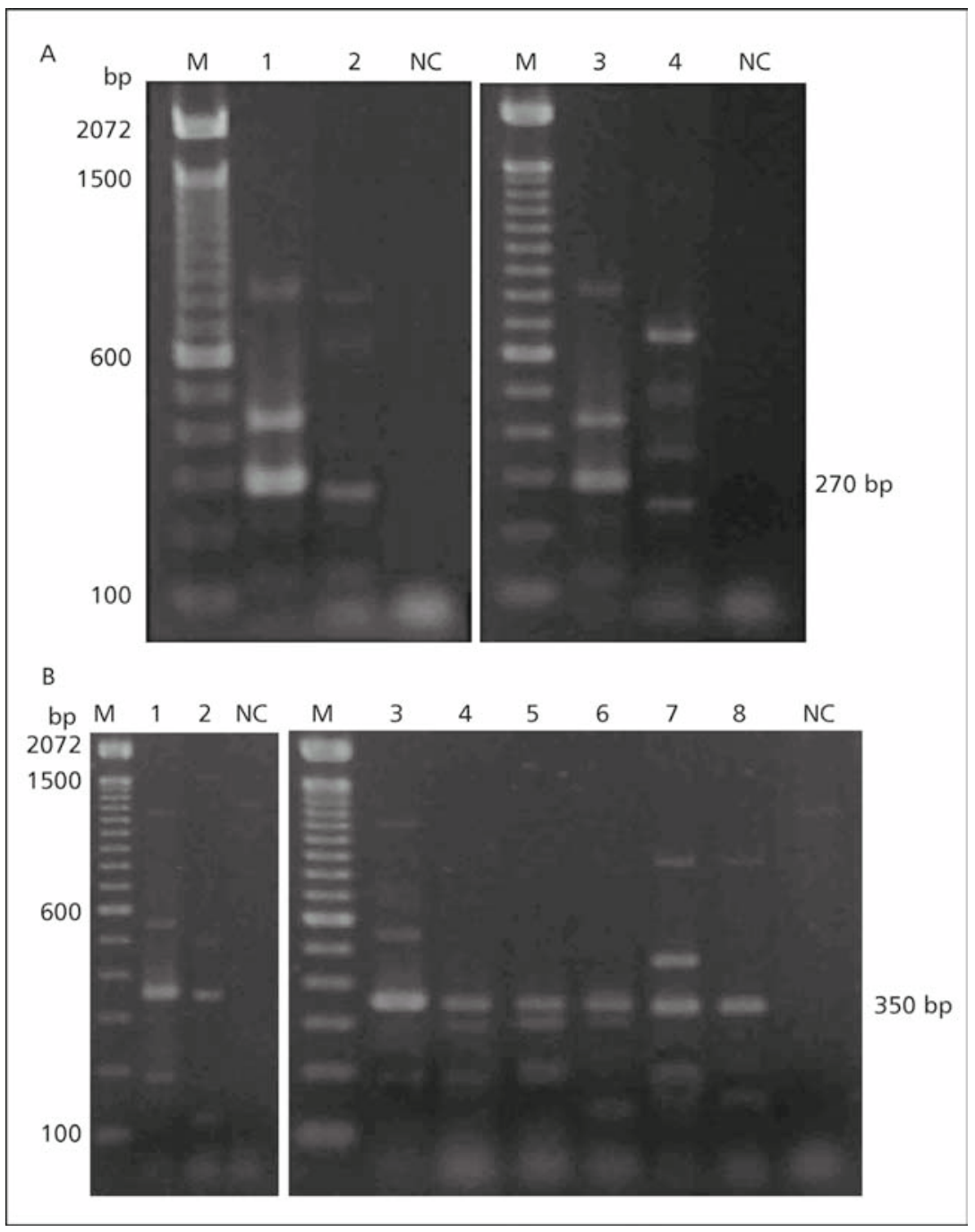

Fig. 2 - Agarose gel (1-1.5\%) of PCR products amplified. (M) Molecular weight marker (100 bp, Gibco/BRL); (NC) negative control; (A) products obtained from cryl genes: (1) Bt aizawai; (2) Bt HA52; (3) Bt aizawai; (4) Bt HA58; (B) products obtained from cry9 genes: (1) Bt aizawai; (2) Bt HA2; (3) Bt aizawai; (4) Bt HA48; (5) Bt HA52; (6) Bt HA53; (7) Bt HA56; (8) $B t$ HA57.

The isolates of our study may provide new agents for biological control of leaf-cutting ants of the Acromyrmex genus. Another possible long-term strategy is the use of $B t$-transgenic plants in the field.
The results of gene amplification here described for the new isolates point strongly to them as good gene sources for developing transgenic plants resistant to insect pests. 
Acknowledgments - This work was supported by EEA/IRGA, UNISINOS, and FAPERGS.

\section{REFERENCES}

ABBOTT, W. S., 1925, A method of computing the effectiveness of insecticide. J. Econ. Ent., 18: 265-67.

ALVES, S. B., 1998, Controle Microbiano de Insetos. 2.ed. FEALQ, Piracicaba, 1163p.

ATLAS, R. M. \& BARTHA, R., 1998, Microbial ecology: fundamentals and applications. Cummings Science Publishing, 694p.

BEN-DOV, E., ZARITSKI, A., DAHAN, E., BARAK, Z., SINAI, R., MANASHEROB, R., KHAMRAEV, A., TROITSKAYA, E., DUBITSKY, A., BEREZINA, N. \& MARGALITH, Y. 1997, Extended screening by PCR for seven cry-group genes from field-collected strains of Bacillus thuringiensis. Appl. Environ. Microbiol., 63: 4883-4890.

BEN-DOV, E., WANG, Q., ZARITSKY, A., MANASHEROB, R., BARAK, Z., SCHNEIDER, B., KHAMRAEV, A., BAIZHANOV, M., GLUPOV, V. \& MARGALITH, Y., 1999, Multiplex PCR screening to detect cry9 genes in Bacillus thuringiensis strains. Appl. Environ. Microbiol., 65: 3714-16.

BERNHARD, K., JARRET, P., MEADOWS, M., BUTT, J., ELLIS, D. J., ROBERTS, G. M., PAULI, S., RODGERS, P. \& BURGES, H. D., 1997, Natural isolates of Bacillus thuringiensis: worldwide distribuction, characterization, and activity against insect pests. J. Invertebr. Pathol., 70: 59-68.

BOARETTO, M. A. C. \& FORTI, L. C., 1997, Perspectivas no controle de formigas cortadeiras. Série Técnica IPEF, FCA/UNESP, 11(30): 31-46.

BRAVO, A., SARABIA, S., LOPEZ, L., ONTIVEROS, H., ABARCA, C., ORTIZ, A., ORTIZ, M., LINA, L., VILLALOBOS, F. J., PEÑA, G., NUÑEZ-VALDEZ, M., SOBERÓN, M. \& QUINTERO, R., 1998, Characterization of cry genes in a Mexican Bacillus thuringiensis strain collection. Appl. Environ. Microbiol., 64: 4965-4972.
BUENO, O. C., MORINI, M. S. C., PAGNOCCA, F. C., HEBLING, M. J. A. \& SILVA, O. A., 1997, Sobrevivência de operárias de Atta sexdens rubropilosa Forel (Hymenoptera: Formicidae) isoladas do formigueiro e alimentadas com dietas artificiais. An. Soc. Entomol. Brasil., 26: 107-113.

DE BARJAC, H. \& LECADET, M. M., 1976, Dosage biochimique d'exotoxine thermostable de. Bacillus thuringiensis d'après l'inhibition d'ARN-polymerases bacteriennes. C. R. Acad. Sci., 282: 2119-2122.

DIEHL-FLEIG, E., 1995, Formigas: organização social e ecologia comportamental. Ed. UNISINOS, São Leopoldo, 168p.

HANSEN, B. M., DAMGAARD, P. H., EILENBERG, J. \& PEDERSEN, J. C., 1998, Molecular and Phenotypic characterization of Bacillus thuringiensis isolated from leaves and insects. J. Invertebr. Pathol., 71: 106-114.

HANSEN, B. M. \& HENDRIKSEN, N. B., 2001, Detection of enterotoxic Bacillus cereus and Bacillus thuringiensis strains by PCR analysis. Appl. Environ. Microbiol., 67: 185-189.

HÖFTE, H. \& WHITELEY, H. R., 1989. Insecticidal crystal proteins of Bacillus thuringiensis. Microbiol. Rev., 53: 242-255.

JUÁREZ-PÉREZ, V. M., FERRANDIS, M. D. \& FRUTOS, R., 1997, PCR-based approach for detection of novel Bacillus thuringiensis cry genes. Appl. Environ. Microbiol., 63: 29973002.

MAAGD, R. DE, BRAVO, A. \& CRICKMORE, N., 2001, How Bacillus thuringiensis has evolved specific toxins to colonize the insect world. Trends in Genetics, 17: 193-199.

NAIMOV, S., WEEMEN-HENDRIKS, M., DUKIANDJIEV, S. \& MAAGD, R. A. DE, 2001, Bacillus thuringiensis deltaendotoxin Cry1 hybrid proteins with increased activity against the colorado potato beetle. Appl. Environ. Microbiol., 67: 5328-5330.

SCHNEPF, E., CRICKMORE, N., VANRIE, J. LERECLUS, D., BAUM, J., FEITELSON, J., ZEIGLER, D. R. \& DEAN, D. H., 1998, Bacillus thuringiensis and its pesticidal crystal proteins. Microbiol. Mol. Biol. Rev., 62: 775-806. 